Int. J. Morphol.,

32(3):839-843, 2014

\title{
Metformin Induces Ultrastructural Alterations in Hepatocytes of Spontaneously Hypertensive Rats
}

\author{
La Metformina Induce Alteraciones Ultraestructurales \\ en Hepatocitos de Ratas Espontáneamente Hipertensas
}

Rajendra Gharbaran*

GHARBARAN, R. Metformin induces ultrastructural alterations in hepatocytes of spontaneously hypertensive rats. Int. J. Morphol., 32(3):839-843, 2014.

SUMMARY: Metformin, an oral biguanide approved for the treatment of type II diabetes is widely prescribed for other clinical conditions. Currently, metformin is being investigated as potential anti-tumor agent. However, there have been recent concerns about hepatotoxicity associated with the use of metformin. This study, by means of high resolution transmission electron microscopy (TEM) and morphometry, investigated potential ultrastructural changes induced by metformin treatment on the hepatocytes of spontaneously hypertensive rats (SHR). Morphometric analysis was carried out on images of randomly selected cells from sectioned gluteraldehyde-osmium-fixed, Epon embedded liver tissue. One-way analysis of variance (ANOVA) on morphometric data showed statistically significant differences in the mean volume density (MVD) of lipid bodies ( $\mathrm{F}=136.48, \mathrm{P}<0.0001)$ and mean surface density $(\mathrm{MSD})$ of endoplasmic reticulum $(\mathrm{ER})$ $(\mathrm{F}=12.45, \mathrm{P}<0.003)$ between hepatocytes of control $(\mathrm{n}=8)$ and metformin-treated $(\mathrm{MT})(\mathrm{n}=8)$ animals. MVD for control group was $5.42 \%$ $( \pm 0.36 \mathrm{SEM})$ but decreased significantly in the MT group $(1.13 \%, \pm 0.04 \mathrm{SEM})$. Similarly, MSD of ER for control was $24.7 \mu \mathrm{m}^{2} / \mu \mathrm{m}^{3}( \pm 1.64$ SEM) but decreased for MT animals $\left(18.90 \mu \mathrm{m}^{2} / \mu \mathrm{m}^{3}, \pm 0.28 \mathrm{SEM}\right)$. These data are most likely consistent with the effects of metformin on lipid metabolism, and may not reflect on hepatotoxicity induced by the drug, in SHRs.

KEY WORDS: Metformin; Rats; TEM; Cancer; Diabetes.

\section{INTRODUCTION}

Almost 20 years ago, the orally-available biguanide drug metformin (Glucophage) was approved by the US Food and Drug Administration (FDA) for the treatment of type II diabetes (non-insulin dependent diabetes mellitusNIDDM). Since then, the therapeutic application of metformin has increased. Most recently, metformin gained the attention of some investigators in the oncology community (Berstein et al., 2012; Evans et al., 2005). Metformin appears to suppress constitutively active tumor suppressor pathways in some malignancies (Green et al., 2010). As a consequence, the use of metformin may become more widespread, as physicians look for cheaper but effective alternative for cancer treatment. However, there is a growing concern about the hepatotoxicity associated with the use of metformin (Cone et al., 2010; Miralles-Linares et al., 2012).

Numerous stimuli including drugs, infections, alcohol, etc., can produce hepatotoxicity, resulting in alterations in structure and content of organelles (Weibel et al., 1969). Hepatotoxicity arising from drug exposure can be determined by various methods including biochemical assays (Eghbal et al., 2013), electron microscopy and morphemetric and stereological analyses. These methods, either alone or in combination, have been used for decades to evaluate changes in cell structure and physiologies.

This present study combined high resolution transmission electron microscopy and morphometry to study potential ultrastructural changes in the hepatocytes of spontaneously hypertensive rats treated with metformin. Among the most profound differences between control $(n=8)$ and metformin-treated $(\mathrm{n}=8)$ animals $(\mathrm{MT})$, were volume density of lipid bodies and the surface density of endoplasmic reticulum. One-analysis of variance (ANOVA) on morphometric data showed lipid volume density was lower in hepatocytes of MT animals than in those of control subjects. Similar statistical analysis showed significantly lower surface density for endoplasmic reticulum for hepatocytes of MT animals compared to controls. These results are likely to be associated with the effects of metformin on lipid metabolism, and may not reflect on hepatotoxicity in this animal model. 


\section{MATERIAL AND METHOD}

Animals. Sixteen two-week old male spontaneously hypertensive rats (SHR), obtained from Taconic Laboratory (Germantown, NY) and housed in the Animal Care Facility of Lehman College were fed a regular diet of rat chow and maintained on a twelve-hour light/dark cycle at room temperature $\left(25^{\circ} \mathrm{C}\right)$. SHRs exhibit defects in carbohydrate and lipid metabolism similar to those found in subjects with essential hypertension such as hyperinsulinemia, impaired glucose tolerance, and reduced insulin-mediated glucose uptake (Buchanan et al., 1992; Mondon \& Reaven, 1988).

Drug Administration. Experimental animals $(\mathrm{n}=8)$ were fed an initial dose of $350 \mathrm{mg} / \mathrm{Kg} /$ day of metformin in their drinking water. The dose was gradually increased to 500 $\mathrm{mg} / \mathrm{Kg} /$ day for the first two weeks, and maintained at this dose for an additional two weeks. At the end of the fourweek metformin treatment, rats were anaesthetized with ketamine $(40 \mathrm{mg} / \mathrm{Kg})$ followed by xylaxine $(25 \mathrm{mg} / \mathrm{Kg})$, and tissue from liver of each animal was immediately removed for the ultrastructural study. Control group $(n=8)$ was fed only drinking water. All procedures were performed in accordance with the Lehman College Institutional Animal Care and Use Committee and the National Institutes of Health guidelines for the care and use of experimental animals.

Tissue preparation and fixation. Freshly obtained liver tissue was diced into $1 \mathrm{~mm}^{3}$, fixed in $3 \%$ gluteraldehyde in $0.1 \mathrm{M} \mathrm{Na}-\mathrm{K}$ phosphate buffer ( $\mathrm{pH}$ 7.2) for one hour at room temperature, rinsed in phosphate buffer and then post-fixed for one and a half hour in $1 \%$ osmium tetraoxide $\left(\mathrm{OsO}^{4}\right)$ in $0.1 \mathrm{M} \mathrm{Na}-\mathrm{K}$ phosphate buffer ( $\mathrm{pH}$ 7.2). After post-fixing, tissue was rinsed in the aforementioned buffer and dehydrated in graded ethanol $(50 \%, 70 \%, 95 \%, 100 \%, 100 \%$, $100 \%$ ), and propylene oxide (3 changes), and embedded in epoxy resin, Epon (eight blocks per subject) which was polymerized in an oven maintained at $65^{\circ} \mathrm{C}$, for 72 hours (Luft, 1961). Blocks from each animal were trimmed, exposing embedded tissue. Sections from each block were cut with Reichert Ultracut-S ultramicrotome using a diamond knife. Silver-gold (60-90 nm thick) sections were selected and mounted on 300-meshed copper grids. Sections were then stained first with lead citrate for five minutes, then in saturated aqueous uranyl acetate (10\%) for 40 minutes, then in freshly centrifuged or filtered lead citrate for another 20 minutes (Daddow, 1983).

Transmission electron microscopy. Mounted sections were examined in a Hitachi H-7000 electron microscope at 75 Kilovolts and at magnification of 2000 (for volume density) and 5000 (for surface density). Fields were photographed with Kodak EM film and the negatives were enlarged to give a final magnification of $8000 \mathrm{X}$ and 21,700 $\mathrm{X}$ for volume density and surface density, respectively.

Computation and Morphometric Analysis. Whole mononucleated liver cells from randomly selected sections of each grid were photographed. A total of 80 micrographs (10/animal) of whole cells per group were obtained for morphometric analysis. Volume density were performed by point counting method (Weibel). A grid system with dots 75 millimeters apart and connected with parallel lines was used for scoring. This grid was randomly placed over each print and counts were made of dots falling on the item of interest (Cornejo et al.). From the counts of total dots over the whole cell, volume density was calculated as described (Weibel) and expressed as a percent of the whole cell occupied by the item of interest. For surface density of cytoplasmic membranes (endoplasmic reticulum), the upper right hand corner of cells' cytoplasm was taken at an initial magnification of 5000 and enlarged to total magnification of 21,700 times. Scoring of line intercepts of endoplasmic reticulum was done by randomly placing over the micrographs, a series of parallel lines occupying an area of $40 \mathrm{~cm}^{2}$ and counting the number of times the membranes intersect the lines within the square area. From these data the surface density of endoplasmic reticulum was calculated as described (Weibel).

Statistical Analysis. Statistical data analysis was carried out using SAS 9.1.3 (SAS Institute Inc.) and StatView 5.0 (SAS Institute Inc.). Data from the volume density and surface density of were determined from the 80 cells per group and expressed as Means \pm SEM. One-way analysis of variance (ANOVA) was used to test for differences between the means of control and MT groups.

\section{RESULTS}

Morphometry was used on high resolution electron microscopic images to determine ultrastructural changes of MT on rat hepatocytes. Although the analysis was carried out for different subcellular organelles, the most profound and significant effects were detected for lipid bodies and the endoplasmic reticulum.

Changes in cellular lipid content. Lipid bodies (L) appeared as huge, gapping, round holes in the sections of control (Fig. 1A) but were either less prevalent or completely absent from hepatocytes of animals from the MT group (Fig. 1B). This qualitative observation was validated by one-way ANOVA 

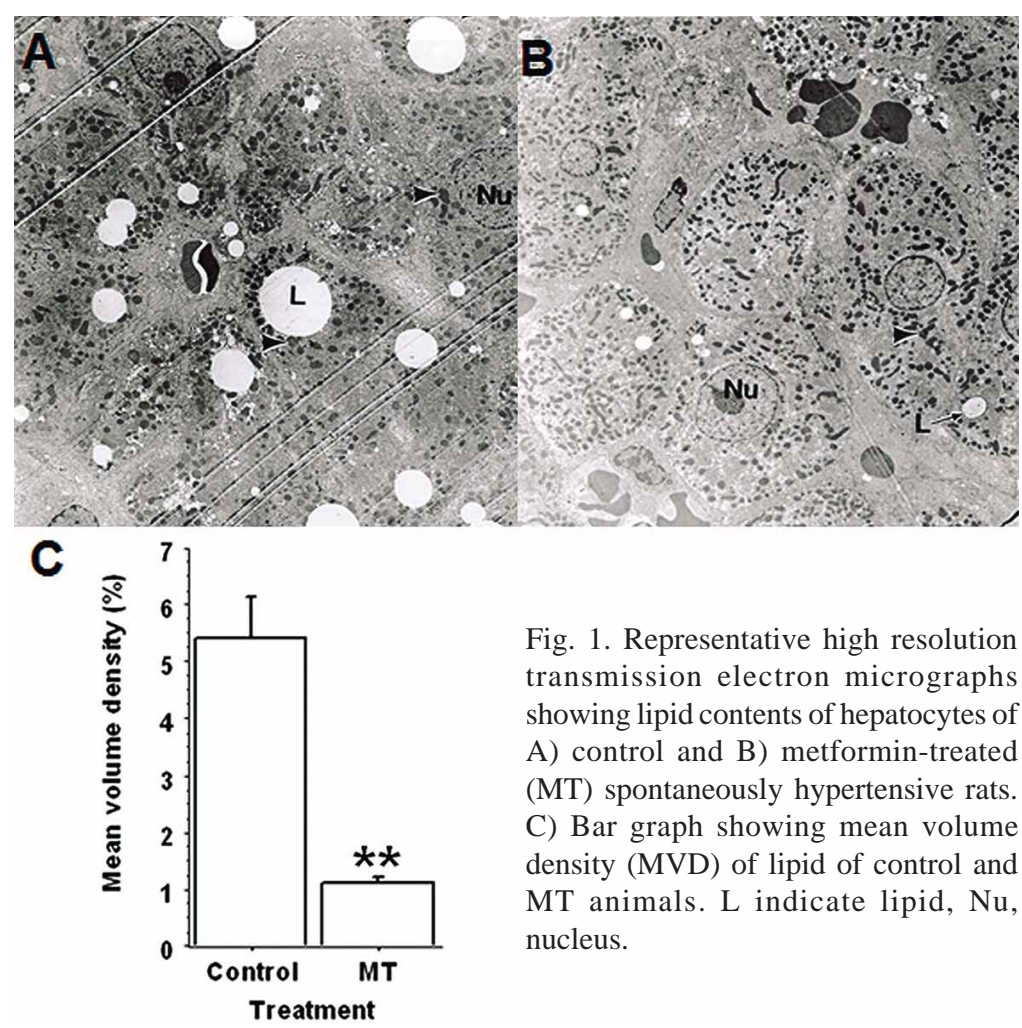

Fig. 1. Representative high resolution transmission electron micrographs showing lipid contents of hepatocytes of A) control and B) metformin-treated (MT) spontaneously hypertensive rats. C) Bar graph showing mean volume density (MVD) of lipid of control and MT animals. L indicate lipid, $\mathrm{Nu}$, nucleus.
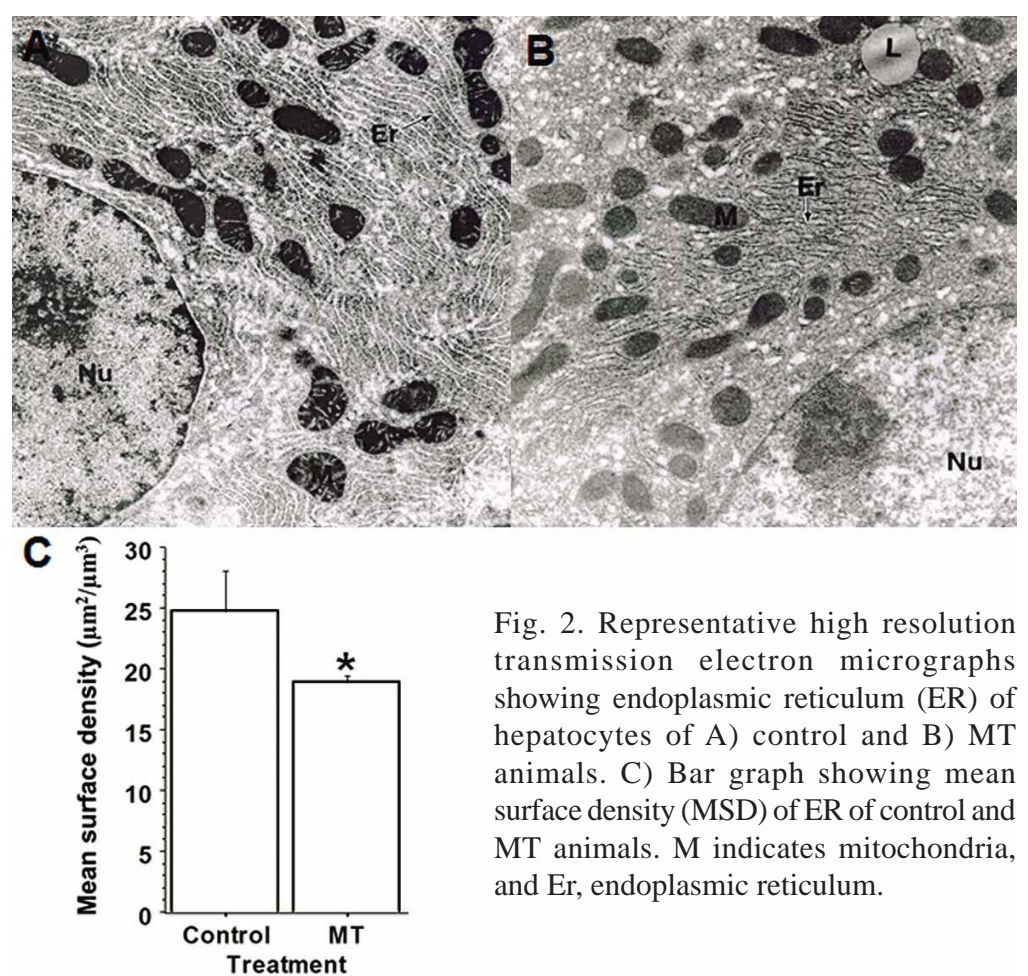

Fig. 2. Representative high resolution transmission electron micrographs showing endoplasmic reticulum (ER) of hepatocytes of A) control and B) MT animals. C) Bar graph showing mean surface density (MSD) of ER of control and MT animals. M indicates mitochondria, and Er, endoplasmic reticulum.

on morphometric data. There was a highly significant difference between the mean volume density of lipid bodies of control and that of MT hepatocytes $(\mathrm{F}=136.48, \mathrm{P}<0.0001)$ (Table I). Mean volume density for control cells was $5.42 \%( \pm 0.36 \mathrm{SEM})$ and that for the treated group $1.13 \%$ ( \pm 0.04 SEM) (Table II). This represents morphometrically, approximately $79 \%$ decrease in basal lipid metabolism.

Decrease in surface density of endoplasmic reticulum. One-way ANOVA analysis was also carried out on the surface density data of endoplasmic reticulum. There was significant difference between surface density of control and MT $-\mathrm{F}=12.45, \mathrm{P}<0.003$ (Table III, Fig. 2). Mean surface density for control was 24.7 $\mu \mathrm{m}^{2} / \mu \mathrm{m}^{3}( \pm 1.64 \mathrm{SEM})$ and that for MT group was $18.90 \mu \mathrm{m}^{2} / \mu \mathrm{m}^{3}( \pm 0.28$ SEM) (Table II). This represents a decrease of $16.77 \%$ in surface density or surface area of endoplasmic reticulum.

\section{DISCUSSION}

The morphometric data indicated that metformin treatment caused a steep decrease in basal cellular lipid content of the liver cells. The in vivo data in this study is consistent with in vitro studies in which metformin treatment resulted in decrease basal lipogenesis of cultured rat hepatocytes (Melin et al., 1990). Metformin also inhibited lipid biosynthesis in liver and intestine (Marquié, 1978) and accelerated the spontaneous regression of excess lipids in the liver of cholesterol-induced atherosclerosis rabbits (Marquie, 1979). These combined effects of metformin may lead to a decrease in body weight and normalize serum lipid profile in obese type II diabetes (Bailey et al., 1992; Hermann, 1979; Vigneri \& Goldfine, 1978). Metformin elicits its antilipidemic roles by activating monophosphateactivated protein kinase (AMPK) or by inhibiting lipogenic enzymes (Bhalla et al., 2012). Consistently elevated serum lipids and obesity have been linked to chronic inflammation which is an important risk factor in the development of malignancies (Melvin et al., 2013; Ramos-Nino, 2013). Therefore, the anti-lipidemic role of metformin may reduce inflammation and subsequently reduce risk of developing cancer. Indeed, metformin is currently being investigated for 
Table I. ANOVA table for volume density of lipid bodies.

\begin{tabular}{lccccc}
\hline Source & DF & Sum of Squares & Mean Square & F-Value & P-value \\
\hline Treatment & 1 & 73.659 & 73.659 & 136.48 & 0.0001 \\
Residual & 14 & 7.556 & 0.54 & --- & --- \\
\hline
\end{tabular}

Table II. Summary of morphometric data.

\begin{tabular}{lccc}
\hline Groups & $\boldsymbol{n}$ & $\begin{array}{c}\text { Mean Volume density of } \\
\text { lipid bodies }(\boldsymbol{\%})\end{array}$ & $\begin{array}{c}\text { Mean Surface density of ER } \\
\left.(\boldsymbol{\mu \mathbf { m }} 2 / \boldsymbol{\mu m})^{3}\right)\end{array}$ \\
\hline Control & 8 & $5.42( \pm 0.37)$ & $24.79( \pm 1.64)$ \\
MT & 8 & $1.13( \pm 0.04)$ & $18.91( \pm 0.28)$ \\
\hline
\end{tabular}

Table III. ANOVA table for surface density of endoplasmic reticulum.

\begin{tabular}{lccccc}
\hline Source & DF & Sum of Squares & Mean Square & F-Value & P-value \\
\hline Treatment & 1 & 138.651 & 138.651 & 12.454 & 0.0033 \\
Residual & 14 & 155.859 & 11.133 & --- & --- \\
\hline
\end{tabular}

potential anti-tumor effects, as metformin appears to activate tumor suppressor pathways (Sarfstein et al., 2013; Shaw et al., 2005).

The data also showed the MSD of ER of the hepatocytes of MT rats was significantly reduced compared to that of control subjects. The ER (smooth and rough) functions in the synthesis of enzymes, some of which are important for degradation and/or synthesis of macromolecules (such as protein, carbohydrates, and lipids). Therefore, decrease of MSD of ER arising from metformin treatment could mean that synthesis of the constitutive enzymes, including those that catalyze lipid biosynthesis, might also be reduced or partly suppressed. This may help to explain the simultaneous decrease in lipid content and surface density of endoplasmic reticulum, due metformin treatment.
The in vivo ultrastructural changes that metformin induced on the hepatocytes in this study may not be an indication of drug toxicity, but an indication of the structural changes that underlie the physiology of the drug, at least in the animal model used in this study.

\section{ACKNOWLEDGEMENTS}

This manuscript was supported by the Department of Biological Sciences, Lehman College of The City University of New York, USA. The autor will like to thank Dr. Dwight Kincaid and Dr. Martin Muntzel and the late Dr. T. E. Jensen, of the Department of Biological Sciences of Lehman College, for their input in this project.

GHARBARAN, R. La metformina induce alteraciones ultraestructurales en hepatocitos de ratas espontáneamente hipertensas. Int. J. Morphol., 32(3):839-843, 2014.

RESUMEN: La metformina, una biguanida oral aprobada para el tratamiento de la diabetes tipo II, es también ampliamente prescrita para otros cuadros clínicos. Actualmente, la metformina está siendo investigada como posible agente anti-tumoral. Sin embargo, ha habido recientes preocupaciones acerca de la hepatotoxicidad asociada con el uso de metformina. En este estudio, por medio de la microscopía electrónica de transmisión (MET) de alta resolución y morfometría, se investigaron los posibles cambios ultraestructurales, inducidos por el tratamiento con metformina, en los hepatocitos de ratas espontáneamente hipertensas (REH). El análisis morfométrico se llevó a cabo en imágenes de células seleccionadas al azar a partir de tejido hepático seccionado, fijado con glutaraldehído-osmio e inmerso en Epon. El análisis de la varianza (ANOVA) de los datos morfométricos mostró diferencias significativas en la densidad de volumen medio (DVM) de cuerpos lipídicos $(\mathrm{F}=136,48, \mathrm{P}<0,0001)$ y la densidad de superficie media (DSM) del retículo endoplasmático (RE) $(\mathrm{F}=12,45, \mathrm{P}<0,003)$ entre los hepatocitos control $(\mathrm{n}=8)$ y los animales tratados con metformina (MT) ( $\mathrm{n}=8)$. La DVM para el grupo control fue de 5,42\% ( $\pm 0,36 \mathrm{EEM})$, pero disminuyó significativamente en el grupo MT $(1,13 \%, \pm 0,04$ EEM). Del mismo modo, la DSM del RE para el grupo control fue de $24,7 \mu \mathrm{m}^{2} / \mu \mathrm{m}^{3}$ ( $\left.\pm 1,64 \mathrm{EEM}\right)$, pero disminuyó para los animales MT $\left(18,90 \mu \mathrm{m}^{2} / \mu \mathrm{m}^{3}, \pm 0,28 \mathrm{EEM}\right)$. Estos datos están probablemente más relacionados con los efectos de la metformina sobre el metabolismo de los lípidos, y no se relacionarían con la hepatotoxicidad por inducción de la droga, en REH.

PALABRAS CLAVE: Metformina; Ratas; Microscopía electrónica de transmisión de alta resolución; Cancer; Diabetes. 


\section{REFERENCES}

Bailey, C. J.; Wilcock, C. \& Day, C. Effect of metformin on glucose metabolism in the splanchnic bed. Br. J. Pharmacol., 105(4):1009-13, 1992.

Berstein, L. M.; Boyarkina, M. P. \& Teslenko, S. Y. Familial diabetes is associated with reduced risk of cancer in diabetic patients: a possible role for metformin. Med. Oncol., 29(2):1308-13, 2012.

Bhalla, K.; Hwang, B. J.; Dewi, R. E.; Twaddel, W.; Goloubeva, O. G.; Wong, K. K.; Saxena, N. K.; Biswal, S. \& Girnun, G. D. Metformin prevents liver tumorigenesis by inhibiting pathways driving hepatic lipogenesis. Cancer Prev. Res. (Phila.), 5(4):544$52,2012$.

Buchanan, T. A.; Youn, J. H.; Campese, V. M. \& Sipos, G. F. Enhanced glucose tolerance in spontaneously hypertensive rats. Pancreatic beta-cell hyperfunction with normal insulin sensitivity. Diabetes, 41(7):872-8, 1992.

Cone, C. J.; Bachyrycz, A. M. \& Murata, G. H. Hepatotoxicity associated with metformin therapy in treatment of type 2 diabetes mellitus with nonalcoholic fatty liver disease. Ann. Pharmacother., 44(10):1655-9, 2010.

Cornejo, R.; Garrido, O.; Sáez, L.; Bustamante, C. \& Cartes, G. Morphometric analysis of alcoholic microvesicular hepatic steatosis in rats. Int. J. Morphol., 32(2):488-92, 2014.

Daddow, L. Y. A double lead stain method for enhancing contrast of ultrathin sections in electron microscopy: a modified multiple staining technique. J. Microsc., 129(Pt. 2):147-53, 1983.

Evans, J. M.; Donnelly, L. A.; Emslie-Smith, A. M.; Alessi, D. R. \& Morris, A. D. Metformin and reduced risk of cancer in diabetic patients. BMJ, 330(7503):1304-5, 2005.

Eghbal, M. A.; Taziki, S. \& Sattari, M. R. Protective Role of Melatonin and Taurine Against Carbamazepine-induced Toxicity in Freshly Isolated Rat Hepatocytes. Int. J. Morphol. 31(3):1081-9, 2013.

Green, A. S.; Chapuis, N.; Maciel, T. T.; Willems, L.; Lambert, M.; Arnoult, C.; Boyer, O.; Bardet, V.; Park, S.; Foretz, M.; Viollet, B.; Ifrah, N.; Dreyfus, F.; Hermine, O.; Moura, I. C.; Lacombe, C.; Mayeux. P.; Bouscary, D. \& Tamburini, J. The LKB1/AMPK signaling pathway has tumor suppressor activity in acute myeloid leukemia through the repression of mTOR-dependent oncogenic mRNA translation. Blood, 116(20):4262-73, 2010.

Hermann, L. S. Metformin: a review of its pharmacological properties and therapeutic use. Diabete Metab., 5(3):233-45, 1979.

Luft, J. H. Improvements in epoxy resin embedding methods. $J$. Biophys. Biochem. Cytol., 9:409-14, 1961.
Marquié, G. Effect of metformin on lipid metabolism in the rabbit aortic wall. Atherosclerosis, 30(3):165-75, 1978.

Marquie, G. Comparative effects of metformin and phenformin on the progression and regression of cholesterol induced athreosclerosis in rabbits. Paroi Arterielle, 5(4):209-18, 1979.

Melin, B.; Cherqui, G.; Blivet, M. J.; Caron, M.; Lascols, O.; Capeau, J. \& Picard, J. Dual effect of metformin in cultured rat hepatocytes: potentiation of insulin action and prevention of insulin-induced resistance. Metabolism, 39(10):1089-95,1990.

Melvin, J. C.; Holmberg, L.; Rohrmann, S.; Loda, M. \& Van Hemelrijck, M. Serum lipid profiles and cancer risk in the context of obesity: four meta-analyses. J. Cancer Epidemiol., 2013:823849, 2013.

Miralles-Linares, F.; Puerta-Fernandez, S.; Bernal-Lopez, M. R.; Tinahones, F. J.; Andrade, R. J. \& Gomez-Huelgas, R. Metformin-induced hepatotoxicity. Diabetes Care, 35(3):e21, 2012.

Mondon, C. E. \& Reaven, G. M. Evidence of abnormalities of insulin metabolism in rats with spontaneous hypertension. Metabolism, 37(4):303-5, 1988

Ramos-Nino, M. E. The role of chronic inflammation in obesityassociated cancers. ISRN Oncol., 2013:697521, 2013.

Sarfstein, R.; Friedman, Y.; Attias-Geva, Z.; Fishman, A.; Bruchim, I. \& Werner, H. Metformin downregulates the insulin/IGF-I signaling pathway and inhibits different uterine serous carcinoma (USC) cells proliferation and migration in p53-dependent or -independent manners. PLoS One, 8(4):e61537, 2013.

Shaw, R. J.; Lamia, K. A.; Vasquez, D.; Koo, S. H.; Bardeesy, N.; Depinho, R. A.; Montminy, M. \& Cantley, L. C. The kinase LKB1 mediates glucose homeostasis in liver and therapeutic effects of metformin. Science, 310(5754):1642-6, 2005.

Vigneri, R. \& Goldfine, I. D. Role of metformin in treatment of diabetes mellitus. Diabetes Care, 10(1):118-22, 1987.

Weibel, E. R. Stereological principles for morphometry in electron microscopic cytology. Int. Rev. Cytol., 26:235-302, 1969.

\section{Correspondence to:}

Rajendra Gharbaran, PhD

Department of Biological Sciences, Lehman College

The City University of New York

250 Bedford Park Boulevard, Bronx, NY 10469

New York

USA

Received: 03-06-2014

Accepted: 27-06-2014

Email: rajeng2@yahoo.com gharbaranr@gmail.com 